\title{
The Historical Impact of Evolution of Mao Zedong's Ethical Thought in the Period of Democratic Revolution
}

\author{
Fang SUN ${ }^{1,2, *}$ \\ ${ }^{1}$ School of Marxism, Tsinghua University, Beijing 100084, China \\ ${ }^{2}$ School of Ideological and Political Theory Teaching, North China Electric Power University, \\ Baoding 071003, China \\ afangsun@126.com \\ ${ }^{*}$ Corresponding author
}

Keywords: Democratic Revolution, Mao Zedong, Ethic Thoughts, Evolution

\begin{abstract}
In democratic revolution period Mao's ethical thought has experienced a historical evolution: world outlook evolved from 'Sages Genesis' to 'People are creating the motive power of history'; outlook on life evolved from 'Three Immortality' state to 'serve the people wholeheartedly'; values evolved from 'spiritual individualism' to 'collectivism'. These evolutions reconstruct the value system and discourse system of the Democratic Revolution, constantly changing and reshaping people's values, ethics, customs and culture, mobilizing and precipitating the workers and peasants to participate in the revolutionary struggle against imperialism and feudalism and making them become the main force of the Chinese revolution.
\end{abstract}

\section{Introduction}

'A given culture (as ideology culture) is the ideological reflection of the politics and economics of a given society, but also operate on and influence the given political and economic form;' [1] and the ethics issues in the culture is also a highly debated and with much concerned problem when the society is facing a period of significant change. To some extent, politics and economic reform are often claims of innovation in moral terms as to preparing public opinion and thought-leader. In Democratic Revolution Period, youth Mao Zedong's ethical thinking has a historical evolution in the background of Chinese and Western cultural interaction. His worldview evolved from 'Sages Creation' to 'the people are the driving force to make history', his life evolved from "Three Immortality" state to "serve the people wholeheartedly", and his values evolved from "spiritual individualism" to "collectivism" in the background of Chinese and Western cultural interaction and gradually formed the ethical ideas of Marxism. Formation of this ethics is a process of gradually construction and this process is also contributed to the reconstruction of the value systems and the discourse system in Democratic Revolution Period, constantly changing and reshaping people's values, ethics, customs and culture, mobilizing and precipitating the workers and peasants to participate in the revolutionary struggle against imperialism and feudalism and making them become the main force of the Chinese revolution.

\section{Reconstruction of the value system during the period of democratic revolution}

\section{Leading social thought and achieve the cultural turn.}

Facing with grave national crisis and social crisis of ancient China, China began the transition from a traditional society to a modern society and the great changes took place in all aspects of economic, political and cultural into the 20th century. At the same time, Chinese ethics achieve a conversion from traditional morality to the modern moral. A variety of doctrine and ideas had been appeared, such as $\mathrm{Wu}$ Hsu giants' reformist ideas of Good Combination of Chinese and Western and the bourgeois-democratic trend which Sun Yat-sen is the representative occupied a dominant position in the 
New Culture Movement. After the May Fourth Movement, issue of "Whither China" once again became the theme of the times. Mao Zedong studied Chinese revolution by applying Marxism-Leninism. First started from the social investigation he made a scientific analysis on various classes in Chinese society and pointed out: 'Who are our enemies? Who are our friends? This is a question of the first importance for the revolution. The reason why China has little effect in all revolutionary struggles is that they can not unite with real friends in order to attack the real enemy.' [2] Then he analyzed the various classes of economic status in Chinese society and searched out the object, motivation, goals and Strategic principles of the revolution. He stressed that the force is strongest when people united, and the main force of China's democratic revolution are farmers. Forget the farmers, there is no Chinese democratic revolution and there would be no revolution. We read many books about Marxist, but it is worth noting that does not forget the word 'farmers'; if you forget the two words, it is no using reading one million books Marxism, because you do not have force. [3] In Chinese history there has no party make people as their moral subject and they are always ethical compliance and performer. Mao's thought, 'people are the motive force in the making of world history,' shattered the Spiritual shackles which set in Chinese people for thousands of years. The thought acted as ideological weapon in 'transformation of China and the World'. In the 'New Democracy', Mao Zedong solemnly declared: 'Not only should we change China from a politically oppressed and economically exploited country into a politically free and economical prosperity country, but also put an ignorance and backwardness China ruled by old culture into an advanced civilization China ruled by new culture. "[1]

Revolutionary war was a head-to-head battle between life and death on political, economic, cultural and military, and 'Revolutionary culture is a powerful revolutionary weapon for the broad masses of the people.' [1] Cultural front was as well a life and death battle in the battlefield. This was because 'a given culture is the ideological reflection of the politics and economics of a given society. There is in China an imperialist culture which is a reflection of imperialist rule, or partial rule, in the political and economic fields....... All culture including enslavement thought is among this category. China also has a semi-feudal culture which reflects her semi-feudal politics and economy, and whose exponents include all those who advocate the worship of Confucius, the study of the Confucian canon, the old ethical code and the old ideas in opposition to the new culture and new ideas. Imperialist culture and semi-feudal culture are devoted brothers and have formed a reactionary cultural alliance against China's new culture....... As for the new culture, it is the ideological reflection of the new politics and the new economy which it sets out to serve...... These new political, economic and cultural forces are all revolutionary forces which are opposed to the old politics, the old economy and the old culture. ' [1] Mao pointed out 'this cultural force, armed with new outfit and new weapons, combined all possible allies, laid out his battle and made a heroic attack toward imperialism culture and feudal culture.' [1] Lu Hsun was the greatest and the most courageous standard-bearer of this new cultural force. 'Lu Hsun was a man of unyielding integrity, free from all sycophancy or obsequiousness; this quality is invaluable among colonial and semi-colonial peoples. Representing the great majority of the nation, Lu Hsun breached and stormed the enemy citadel; on the cultural front he was the bravest and most correct, the firmest, the most loyal and the most ardent national hero, a hero without parallel in our history. The road he took was the very road of China's new national culture. '[1] 'A national, scientific and mass culture--such is the anti-imperialist and anti-feudal culture of the people, the culture of New Democracy, the new culture of the Chinese nation .'[1] Mao Zedong's 'people-centered' value beginning and the value goal of communism, mobilizing the broad participation of the masses of the population $90 \%$ in China to the people's culture and the people's war torrent. Finally, Marxism culture became the main line in the collision, communication, interaction of Marxism, Chinese and western culture.

\section{Constructing revolutionary morality of 'serving the people as the core'}

The mind of 'Serving the People' from moral to become the Chinese Communists' values, outlook and all career's purposes, is the final outcome of the Mao Zedong's Thought ethical evolution in Democratic Revolution. 'Serving the People' is the quality of the Communists, but also the starting point and end point of all work to Communists. 'Our Congress should call on the whole Party to pay 
attention to every comrade on every aspect of work, do not let him out of the masses. And Our Congress should teach every comrade to love the people and listen carefully to the voice of the masses; We should identified ourselves with the masses and deep among the masses but not stand above the masses wherever we went; We should inspire and raise the consciousness of the masses under the principle of Voluntary heart according to the degree of consciousness of the masses and help people organize together gradually, gradually expanded as time permitted by the local and external environment and all necessary struggle.' [4] Our army 'should not combine and fight for a few people or a group of narrow self-interest, but for the interests of the broad masses of the people, for the benefit of the whole nation, and what should Chinese do is stand firmly together and dedicate to serve the people of China, is the only purpose of this army.' [4] Mao Zedong called on the whole party and the entire army studying Comrade Bethune's spirit, his utter devotion to others without any thought of self. He thought that 'a people have different abilities, but if he has this spirit, he is a noble man, a pure man, a moral man, a man from the vulgar, and a benefit to the people.' [1] Only when we put our own life and death with interests of the people and the liberation cause of people together, can we have value and meaning of life. 'All men are mortal, but death has a different meaning. In ancient China, a writer named Sima Qian said that though death befalls all men alike, and it may be weightier than Mount Tai or lighter than a feather. To die for the people is weightier than Mount Tai. To work for the fascists, to die for the exploiters and oppressors of the people, is lighter than a feather.' [4] 'Hence, selfishness, slacking, corruption, seeking the limelight, and so on, are most contemptible, while selflessness working with all one's energy, whole-hearted devotion to public duty, and quiet hard work will command respect. ' [1] Putting interests of the people in the highest, which is the Mao's ideological theory summary and generalization of traditional Chinese cultural morality and the developed revolutionary practice, the revolutionary moral law of Chinese Communist in democratic revolution.

\section{Reconstruction of the Democratic Revolution discourse system}

\section{Construction of Marxism Nationalization semantic field}

Mao Zedong pointed out in the 'New Democracy': A splendid old culture was created during the long period of Chinese feudal society. To study the development of this old culture, to reject its feudal dross and assimilate its democratic essence is a necessary condition for developing our new national culture and increasing our national self-confidence. [1] China's present new politics and new economy have developed out of her old politics and old economy, and her present new culture, too, has developed out of her old culture; therefore, we must respect our own history and must not lop it off. [1] Tradition has such enormous spiritual force of inertia that any thinker of any nation can not completely abandon the traditional. When Mao starting his ethical thinking, he made carriers of traditional Chinese culture as the reflection of the Marxist Ethics with embodied .He built the nationalization of semantic field when promoted Marxism to people.

'The application of Marxism for Chinese Communists should also like this. We must unify the universal truth of Marxism and the concrete practice of China's entirely appropriately, that means, it is useful only when combined with national characteristics and experienced a certain amount of national form, besides, it must not be applied subjectively formula. ...... Chinese culture should have its own form, its own national form. [1] Mao Zedong does it personally and his many important expositions in democratic revolution have cited the "Analects of Confucius". Such as in the article of "Report on the Peasant Movement in Hunan', Mao said that 'Soon after my arrival in Changsha, I met all sorts of people and picked up a good deal of gossip. From the middle social strata upwards to the Kuomintang right-wingers, there was not a single person who did not sum up the whole business in the phrase, it's terrible!' [2] This phrase 'in one words' is from The Analects - for the government; the paper 'Statement on Chiang's statement' point out: 'From now on the question is whether he will carry out to the letter his pledge that promises must be kept and action must be resolute.'[2] ' be truthful in speech and firm in action' is from The Analects - XIII, besides, Mao also explain and preach Marxism to the 
majority of the workers and peasants by citing words like 'help in the field', 'haste makes waste', 'insatiable in learning, indefatigable' which is from The Analects. 'On Practice' is Mao's famous paper and its subtitle is 'on the relationship between knowledge and practice - the relationship between knowledge and practice,' and it clearly show that he inherited national characteristics of the ancient Chinese knowledge and practice theory.

\section{Construction of Marxism popularization semantic field}

Mao Zedong once pointed it out clearly early in the Agrarian Revolutionary War: 'It is not enough to set tasks; we must also solve the problem of the methods for carrying them out. If our task is to cross a river, we cannot cross it without a bridge or a boat. Unless the bridge or boat problem is solved, it is idle to speak of crossing the river. Unless the problem of method is solved, talk about the task is useless. ' [2] And this bridge, the ship is popular, that is, the use of a public voice applied in publicity and education and Universal use. 'If we do not know how to speak what people learn, then the masses can not comprehend our resolutions.' [4]

Mao Zedong insisted described the profound principle of revolutionary theory of Marxism in plain national language, in a way, he even uses a similar 'reform translated' way to introduce the revolutionary theory of Marxism, and strive to make the text of the presentation can be close to China people. In a way, he even uses a similar 'reform translated' way to introduce the revolutionary theory of Marxism, and strive to make the presentation of the text can be close to the Chinese people.

\section{Acknowledgement}

This research was financially supported by the Fundamental Research Funds for the Central Universities under Grant No. 13MS122 and Social Science Foundation of Hebei province under Grant No.HB14MK031.

\section{References}

[1] Mao Zedong. "Selected Works of Mao" [M ], volume 2, Beijing: People's Publishing House, 1991.

[2] Mao Zedong "Selected Works of Mao" [M] Volume 1, Beijing: People's Publishing House, 1991.

[3] Mao Zedong "Works of Mao Zedong" [M] Volume 3, Beijing: People's Publishing House, 1996.

[4] Mao Zedong "Selected Works of Mao" [M] Volume 3, Beijing: People's Publishing House, 1991. 